\title{
Vineyards characteristic by using GIS and reflectance measurements on the Nagy-Eged hill in Hungary
}

\author{
Fórián, T. ${ }^{1}$, Nagy, A. ${ }^{1}$, Riczu, P. ${ }^{1}$, Mézes, L. ${ }^{1} \&$ Tamás, J. ${ }^{1}$ \\ ${ }^{1}$ University of Debrecen, Centre of Agricultural Sciences and Engineering, Faculty of Agricultural and Food Sciences and \\ Environmental Management, Institute of Water and Environmental Management, \\ H-4032 Debrecen, Böszörményi 138, Hungary forian@agr.unideb.hu
}

\begin{abstract}
Summary: Our investigation was carried out in vineyards on Nagy-Eged hill in Hungary. Grapevine growing plays an important role in Eger Vine Regions. In the grapevine cultivation it becomes necessary to know the requirements of vineyards along the best geographical situation using available cultivation and examination technology to achieve better and quality produce. This study reviews applicability of the different spatial analyst techniques in vineyard especially models based on surface relief and the new technology of hyperspectral analysis. The spectral alteration was examined between different health status and leaves infected by Eriophyes vitis to define spectral characteristics. Thus reflectance measurements could also support to evaluate airborne hyperspectral images with the help of the spectral library.
\end{abstract}

Key words: digital elevation model, aspect, slope, reflectance measurements

\section{Introduction}

Nowadays the applied geoinformatical and the hyperspectral techniques are used in the environmental modelling. To define the effect on soil and vigour of vegetation we have to create a complex model. These questions could be answer efficiently with the help of the geographical information systems and the decision support systems based on geoinformatics (Németh et al., 2007). The precision agriculture and the different technological elements of it become general better in the field of the crop production all over the world and in Hungary also (Tamás, 2001). At the same time, manly experimental applications were taken place in case of the fruit production in Hungary (Firtha, 2006).

Many variables affect the growth of grapevines, which can be integrated in an information system. The geoinformatical modelling and remote sensing are applied in the precision viticulture to classify vineyards (Martinez-Casanovas et al., 2010) and to predict yield (Martinez-Casanovas and Bordes, 2005; Arnó et al., 2005). Our aims is to determine different parameters that can influence grapevine production with the help of the geoinformatics and the spectral characteristics.

\section{Material and methods}

\section{Study area}

Nagy-Eged hill is located on the southern parts of the Bükk Mountains. On the study area, grapevine and wine production have been taken place for almost a thousand years. The Nagy-
Eged hill is the one of the highest grapevine cultivating area in Hungary, and the famous Hungarian red wine (Bikavér) producing started here (Mentusz, 1972). During the 1900's there were several period when the cultivation was let up, finally the area was abandoned from the 60-70's years. The highest part of the hill has been replanted in 2001 (Juhász, 2002).

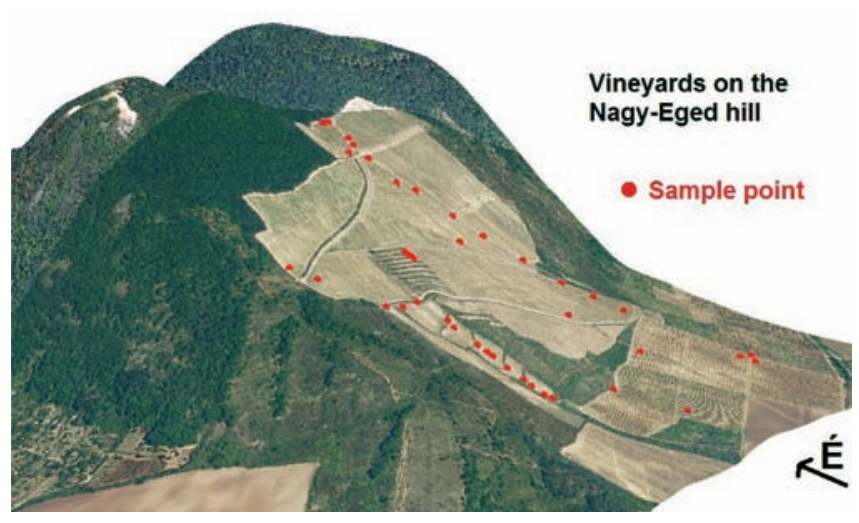

Figure 1: The elevation model of the Nagy-Eged hill and the location of vineyards in 3 dimension view

The vineyards are situated on the southern steep slopes (Figure 1., 2., 3.). At the moment grapevines are cultivated such as Kadarka, Cabernet Sauvignon, Cabernet Franc, Merlot, Pinot Noir and Shiraz. Modern plantations on the Nagy-Eged hill consist of trained vines, usually planted perpendicular to the contour lines and without terraces and irrigation system.

The top and the northern parts of the hill built up of Upper Triassic (Nori) light grey limestone, on which Upper Eocene 
yellowish-white, fine calcareous marl and white nummulitic limestone settled (Sándor, 1983; Kárász, 1991).

The original soil type was humus-rich carbonate rendzina, which can be eroded very easily (Stefanovits, 1956) and bare limestone remains on the surface.

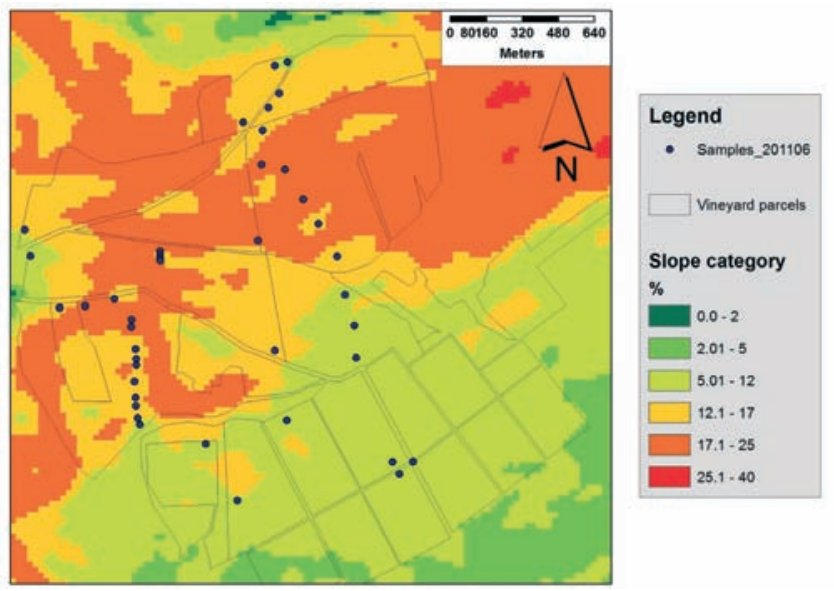

Figure 2: The slope categories of parcels on the Nagy-Eged hill

The upper regions of vineyards are situated on $12-25 \%$ steep slopes (Figure 2.). This area is eroded significantly due to very high slope angle and the cultivation methods of grape parcels. Consequently rainfalls produce heavy soil losses and erosion, the topsoil is very shallow $(0-30 \mathrm{~cm})$. The lower part of the hill is the accumulation area slathering by eroded materials $(100-150 \mathrm{~cm})$.
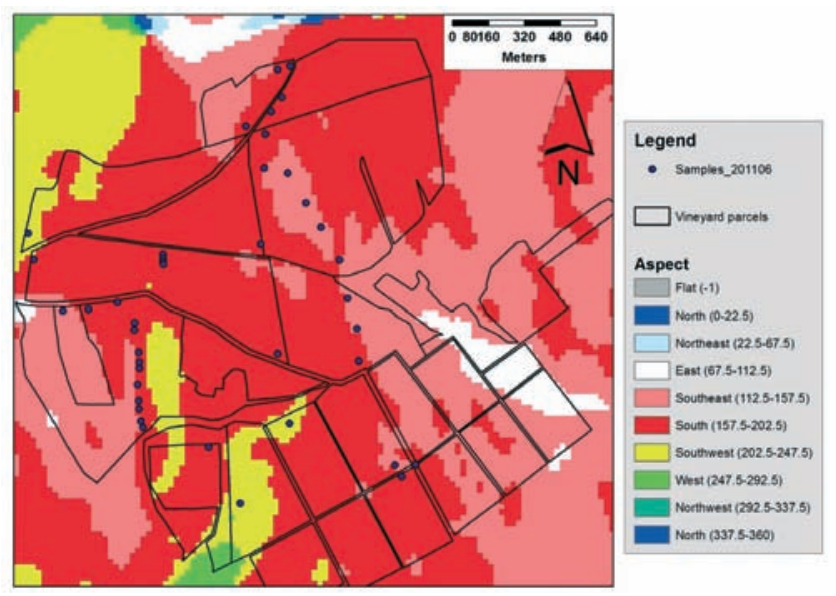

Figure 3: The aspect of parcels on the Nagy-Eged hill

\section{Methods and measurements}

We used the topographical maps with 1:10.000 scale in EOV coordinate system for the vectorization. The methods used survey point elevations and contour lines also digitised from existing maps to describe terrain surface. The surfaces are created using ArcGis 9.2 software 3D Analyst extension. Our database also contained true-colour airborne images.

We have performed primary fieldwork, which were concerned to spatial and attributive data. In the case of spatial data, we used Trimble Juno PDA with integrated GPS, or rather DGPS correction in Terrasync Office environment on the basis of the Trimble Pathfinder geostation archives. The real time fieldwork was applied with processing of MobileGIS ArcPad 8 and Digiterra 6 software's.

43 soil samples were taken on different parts of the slope from $495 \mathrm{~m}$ to $310 \mathrm{~m}$ above see level to measure basic soil parameters (carbonate content, $\mathrm{pH}$, grain size distribution).

Leaves (health and diseased) of grapevine were collected on the sampling points to determine its reflectance spectra and weight. The reflectance spectra were measured by a hyperspectral (0.55 nm spectral resolutions) AvaSpec 2048 spectrometer within 400-1000 nm wavelength interval. The AvaSpec 2048 system consists of a spectrometer, a fiber optic and a halogen light source, and a spectral sampling box. The fiber optic has two connections; one is for the spectrometer, and one is for the light source. The light source ensures the permanent light intensity in the whole measurement range. The sampling box is insulated so any external light does not disturb the sampling. Before the spectral measurement, the spectrometer had to be calibrated. For the calibration white and dark reference measurement is needed. The calibration was made by a special calibration reference unit. For reflection measurements WS-2 reference tiles was used for diffuse reflection The WS-2 white reference tile is made out of a white diffuse PTFE (polytetrafluoroethylene) based material, meeting the highest demands with regard to high grade diffuse reflectance.

The pigment in plant leaves, chlorophyll, strongly absorbs visible light (from 0.4 to $0.7 \mu \mathrm{m}$ ) on the other hand, strongly reflects near-infrared (NIR) light (from 0.7 to $1.1 \mu \mathrm{m}$ ). The reflectance value of the vegetation without any stress is high at NIR intervals, but low at red wavelength interval (Tamás and Szabó, 2010). During the survey NDVI index was calculated from the hyperspectral values.

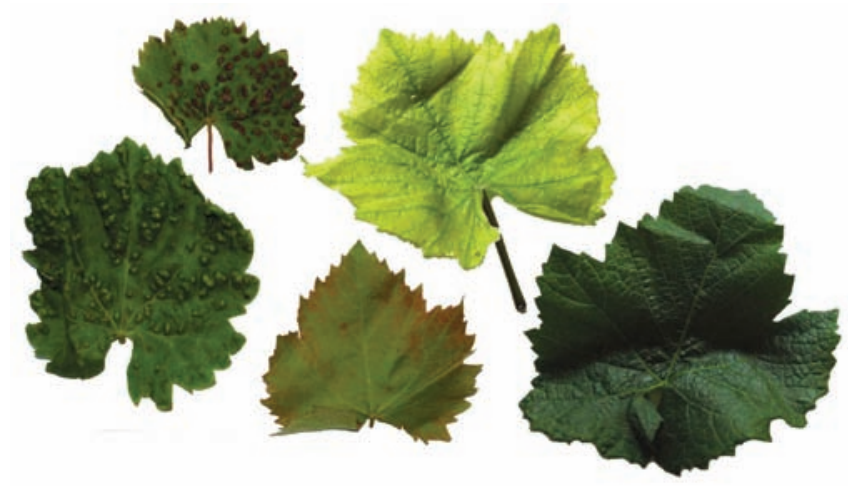

Figure 4: Sample leaves (health green, yellow, red and diseased)

Differences between relative water content of the leaves were also assessed in the near infra red (NIR) zone between 900-970 $\mathrm{nm}$ by the Water Band Index (WBI). WBI is a reflectance measurement that is sensitive to changes in canopy water status (Nagy et al., 2011). As the water content of vegetation canopies increase, the strength of the absorption around $970 \mathrm{~nm}$ increases relative to that of 900 
$\mathrm{nm}$. WBI is defined by the following equitation: $\mathrm{WBI}=\delta 900 /$ $\delta 970$ (Champagne et al., 2001). The dry material content of the leaves was also measured by drying.

\section{Result and discussion}

For the agro-ecological examination of vineyards there is need to derive new raster surfaces from an elevation model include slope, aspect or hillshade tools. These raster data are suitable for to characterize grape parcels, as well as visualization too (Figure 1). These methods result itemized statements from main surface characteristic of every parcel in order to design new investments or further plantations.

The examination area of the Nagy-Eged hill is bound to the viticulture characterized by mainly slopes oriented to south (64\%) and southwest (28\%). It has relatively steep slopes, $17-25 \%$ steep slopes represents $30.3 \%, 12-17 \%$ steep slopes $28.6 \%, 5-12 \%$ slopes $1.6 \%$ and the gentle slopes have $39.3 \%$ ratio.

Because of very thin soil layer in the upper zone of the hill the results of $0-10 \mathrm{~cm}$ soil samples are presented in this paper (Figure 5.). Every soil samples (0-10 cm depth) consists of limestone rocks $(10-3,6 \mathrm{~cm} \varnothing)$. The lowest amount of fine fraction $(<0,2 \mathrm{~cm} \varnothing)$ can be observed in the samples from the middle zone (410-350m above see level), while increase slightly in samples from the upper zone (495 m - next to the forest), the highest ratio of fine fraction can be measured in the accumulation zone $(310 \mathrm{~m})$. The $\mathrm{pH}$ value was $6,34-7,76$.

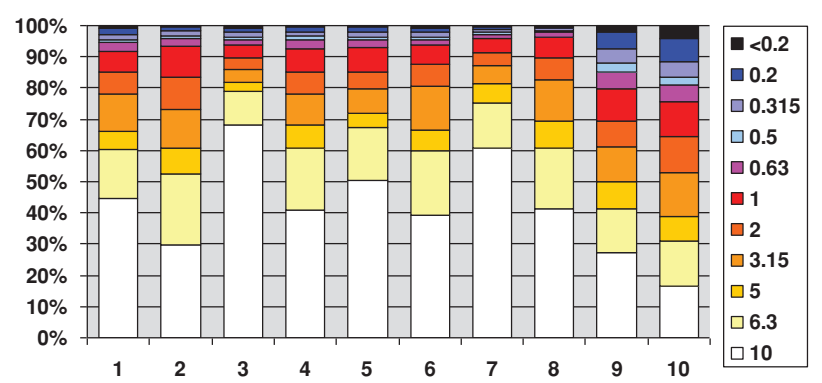

Figure 5: Grain size distribution of soil samples in $0-10 \mathrm{~cm}$ depth, from $495 \mathrm{~m}$ to $310 \mathrm{~m}$ above see level

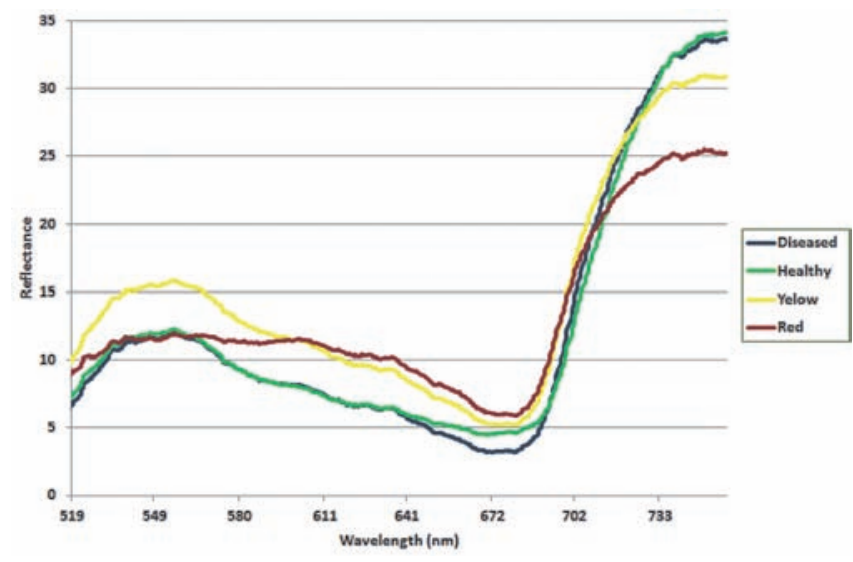

Figure 6: Mean reflectance value of leaves in visible range
The mean NDVI index of the leaves was the highest in the case of the diseased leaves (0.66), health green $(0.63)$, the yellow leaves characterized by lack of Fe (0.52) and finally red leaves characterized by lack of $\mathrm{P}(0.46)$. These differences originated from the variant reflectance values in visible and near-infrared (Figure 6.).

We measured the weight of leaves before and after drying at $105{ }^{\circ} \mathrm{C}$. The mean weight loss of health leaves was $2.3 \mathrm{gr}$, while $1.2 \mathrm{gr}$ in case of leaves infected by Eriophyes vitis is due to water content of grape leaves. The lowest values of the weight loss were measured at the leaves from the middle zone of the hill, where the fine fraction of the soil was also low.

As a result, the differences between the maximum and minimum reflectance values within 900-970 nm wavelength intervals, where the water stress could be detected with the hyperspectral analysis, were high at the leaves originated from the lower part of the hill, and were lower at the upper part of the hill. This phenomenon can be demonstrated in every type of leaves on the Nagy-Eged hill. The correlation between the WBI and the weight loss on the unit leave surface was $R^{2}=0,82$.

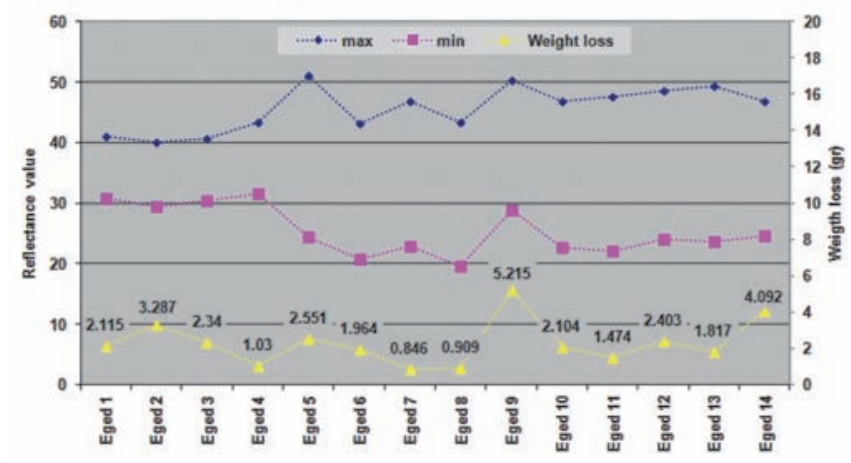

Figure 7: Maximum and minimum reflectance value of green leaves within 900-970 nm wavelength intervals, and the values of the total weight loss of leaves originated from water content (from $495 \mathrm{~m}$ to $310 \mathrm{~m}$ above see level)

\section{Conclusions}

The measured $\mathrm{pH}$ values has no any correlation with the spectral reflectance values of the grapevine leaves on the Nagy-Eged hill. On the basis of the results of the grain size distribution the hill divided into 3 different part according to the fine particle content (upper zone with moderate erosion, middle zone with high erosion, and lower zone with accumulation). The shapes of the spectral curves of the leaves are similar, there are differences among leaves (green, yellow, red and infected by Eriophyes vitis) in intensity and the green-yellow-red (520-730) wavelength interval. Due to the infection by Eriophyes vitis brownish pathes occurred on the leaves surface, therefore the reflectance in the red interval is lower than healty grapevine leaves. The results of the water stress examination (reflectance values within 900-970 nm wavelength intervals and the weight loss on the unit leave surface) show similar relationship to the grain size distribution analysis. 


\section{Acknowledgement}

The authors thank to Tibor Stefán, Stefiko Bt. 3399, Andornaktálya, Rákóczi F. út 160., stefiko@t-email.hu for supporting of field survey.

\section{References}

Arnó, J., Martínez-Casanovas, J. A., Blanco, R., Bordes, X. \& Esteve, J. (2005): Viticultura de precición en Raimat (Lleida): experiencias durante el período 2002-2004. ACE Revista de Enología. Número. 64.

Champagne, C. A., Pattey, E., Bannari, A. \& Stratchan, I.B. (2001): Mapping Crop Water Status: Issues of Scale in the Detection of Crop Water Stress Using Hyperspectral Indices. In Proceedings of the $8^{\text {th }}$ International Symposium on Physical Measurements and Signatures in Remote Sensing, edited by CNES, 79-84. Aussois. France.

Firtha, F. (2006): Controlling and calibration of hyper-spectral measurement, Journal of Food Physics, Budapest, 17-18: 13-28.

Juhász, L. (2002): A Nagy-Eged természeti értékei. Pályázati tanulmány természeti oltalom alá helyezéshez. Debrecen

Kárász, I. (1991): Természetismereti tanösvény a Bükk kapujában a Nagy-Eged hegy. Egri Környezet- és Természetvédelmi Oktatóközpont, Eger
Martínez-Casanovas, J. A. \& Bordes, X. (2005): Viticultura de precisión: Predicción de cosecha a partir de variables del cultivo e indices de vegetacíon. Revista de Teledetección, 24: 67-71.

Martínez-Casanovas, J. A., Agelet, J., Arnó, J., Bordes, X. \& Ramos, M.C. (2010): A protocol for the zonification of intra-field vineyard variability for selective harvesting from multispectral images. Revista de Teledetección, 33: 47-52.

Mentusz, K. (1972): A Bikavér hazája. Középeurópa legmagasabb szőlőskertje az Eged. Népújság. Az MSZMP Heves Megyei Bizottsága és a Megyei Tanács Napilapja. 23: 61.

Nagy, A., Tamás, J., Soltész, M., Nyéki, J. \& Szabó, Z. (2011): Colour and water content detection of sweet cherry by portable spectrometer. International Journal of Horticultural Science, Budapest, 17: (4-5): 27-31.

Németh, T., Neményi, M. \& Harnos, Zs. (2007): Methodology of Precision Agriculture (in Hungarian) JATE Press., pp. 1-238.

Sándor, A. (1983): Kilátás a kövekről - Bükki Nemzeti Park. Mezőgazdasági Kiadó, Budapest

Stefanovits, P. (1956): Magyarország talajai. Akadémiai Kiadó, Budapest

Tamás, J., (2001): Precision agriculture (in Hungarian), Szaktudás Kiadó, Budapest, pp.1-160.

Tamás, J., \& Szabó, Z. (2010): Hyperspectral evaluation of the pear trees on the basis of the genetic collection of the different species. ISPRS TC VII Symposium - 100 Years ISPRS, Vienna, Austria, July 5-7, 2010, IAPRS, 38. Part 7B 